the tissues of the tooth. Nevertheless, the concentrations even in these deeper enamel layers were higher in teeth from high than from low fluoride areas. The lesser solubility of fluorapatite compared with hydroxyapatite suggested a possible mode of action in reducing the incidence of caries, and detailed investigations of solubility were deseribed in which the outer surfaces of teeth from high and low fluoride aroas were compared. The large variation tooth-to-tooth made valid comparison very difficult and the slightly lower solubility found for teeth from a 1 p.p.m. fluorine area, as compared with a zero fluorino area, was not statistically significant. At 2 p.p.m., however, a statistically significant lowering by 21 per cent in the solubility was recorded. The choice of analytical method was of importance in the solubility determina. tions; in some conditions different results were obtained, according to whether phosphorus or calcium was measurod, and workers in the United States had investigated the problem by gravimotric determinations of solubility on powders ground from successive layers of the teeth. By this method, too, the teeth with highest fluoride con. tont were also the most soluble. Experiments with radioactive fluoride revealed that the tooth took up fluorido more readily in the nieghbourhood of a caries blemish, and it had been found that the differences between the fluoride of enamel from areas of high and low intake of fluoride were greater when carious enamol was studied.

Other properties of the fluoride ion were discussed that might be related to its action in reducing dental decay.
Since it favoured the precipitation of calcium phosphate from unstable and metastable solutions, such as saliva, it might intermittently reverse the removal of calcium salts in, and thus slow the development of, a dental cavity. The role of fluoride as an enzyme poison might also be related to its decay-inhibiting properties. Attempts were therefore being made to study the fluoride content of the 'dental plaque' (the muco-bacterial film on the tooth surface) -an analytical problem of some magnitude when it is realized that only about $10 \mathrm{mg}$ of plaque can be obtained from one person. It had been shown to be significantly higher in subjects from 'high fluoride' areas. Partial rolease of the bound fluoride in plaque might occur if the $p \mathrm{H}$ bocamo sufficiently acid, as it probsbly did after eating carbohydrate. It had been found with saliva that the addition of fluoride at a concentration similar to that of plaque was effective not moroly in preventing the production of acid from carbohydrate by salivary bacteria but could actually bring about an increase in $p \mathrm{H}$.

That fluoridation of public water supplies was a subject of great topical interest was evident from the lively discussion that followed each paper. The analyst, it was clear, had an important part to play by devoloping and applying sensitive methods that were essential not only to ensure its proper regulation and control but also to provide the basic tools for the study of the fundamental mechanism by which fluoride exerted its beneficial offoct.

S. A. PrICE

\title{
GROWTH AND NUTRITION OF A WHOLE PLANT
}

A NYONE interested in the growth of the whole plant should find a recently published memoir interesting, for they will find it a refreshing revision course dealing with some theories of contemporary botany in a more stimulating way than is usually found in text-books*. Prepared by Prof. F. C. Steward and three colleagues it contains, in Parts 2-5, information about the anatomy, growth and development of mint grown with a wide range of nutrient-levels (some of which led to deficiency symptoms) and different light and temperature conditions. Parts 4-6 have details of many chemical analyses, involving chromatographical techniques, carried out on roots, stems and leaves of plants grown under a wide range of environmental conditions. The final section is a synthesis of the earlier parts.

Although the morphology of the plant does make it readily acceptable to sampling procedures, the decline in popularity of mint as an experimental plant (discussed in Part 1) must largely be due to the fact that large numbers of plants are usually needed for experiments associated with analysis of growth. Raising plants from seods is more satisfactory from many points of viow than from cuttings. There are no troubles in keeping stock plants

* Growth, Nutrition and Metabolism of Mentha piperita L. Parts 1-7. Memoir 379, Cornell University Agricultural Experimental Station, Ithaca, New York. August 1962, 144 pages. alive, no labour-demanding jobs such as preparing cuttings, and less variation in initial size of plant. The rapid growth rate of mint is obviously valuable; but the fact that it produces much lateral growth and a large number of small leaves is a disadvantage when compared with plants producing a few large leaves from a main axis. The unbranched plant, particularly one the form of which is similar under a wide range of environmental conditions, will, unlike mint, have similar efficiencies of light utilization in, for example, long- and short-day conditions. Would the results of the many chemical analyses that are presented in Parts 4-6 of the memoir have been similar if a plant with a single main axis had been used ?

These first seven parts contain a great deal of informa tion about effects of length of day, night temperature and mineral nutrition on some cell constituents; some information in future parts on effects of amount of incident radiation, spectral composition of light and perhaps other environmental variables would obviously give a more complete picture. Finally, most botanists would agree that the chemical analyses which were done on mature tissues should be extended to the growing regions, not only to apical meristems, but also to all organs throughout periods of cell division, expansion and differentiation if a better understanding of organization of growth is to be obtained.
P. Newton

\section{THE CENTRAL FOOD TECHNOLOGICAL RESEARCH INSTITUTE, MYSORE}

$\mathrm{T}$ is not uncommon to find that scholarly academic work is undertaken in underdeveloped countries while practical problems of vital interest to the economy of the State are neglected. Sometimes technological laboratories equipped with foreign capital do not function satisfactorily because of lack of suitable personnel. Some of these problems are no doubt due to the type of training given to students sent to Europe and elsewhere, but others to lack of proper incentives presented by the Governments concerned. None of these criticisms can, however, bo applied to the Central Food Technological Research Institute at Mysore, which, under its director, Dr. V. Subrahmanyan, is rapidly building a reputation in SouthEast Asia. The report of its work during 1960-61 covers 
many aspects of the food industry and includes biochemistry, nutrition and dietetics*.

Emphasis is properly placed on the solution of problems which have a direct application in Asia, but some of the results are of interest to the European technologist. Tho frying of banana chips, the preparation of buttermilk soup powders, the canning of drinking-water, the utilization of passion fruit waste or the colorization of vanaspati with tumeric would be unusual subjects for study by the Western sciontist. But the preparation of foods for infants and children from largely plant sourcos is well known to be of vital importance not only in India and Asia but also in many other parts of the world. In this respect, the experience of the Indian workers with isolated proteins from groundnut and soya warrants careful attention, especially with regard to the method of presentation to the consumer. Groatest success has been achieved with a high-protein blend of materials designated 'multi-purpose food' which is made on a large scalo and has been used in school-meal programmos as a supplement "to overcome

* Central Food Technological Research Institute, Mysore. Annual Roport, 1960-61. Pp. v + 112. (Mysore: Central Food Technological Research the deficiency of the lunch". The manufacture of this product has now been handed over to private industry.

Similarly, the sections of the report dealing with meat and fish technology, packaging, storage and pesticido research have applications in any tropical country. Of particular value is the work on fish, as this source of protein has been somowhat noglected in tho past; work is being done to oxtend tho use of traditional methods as well as the development of now products. Sun-drying, salting and curing are likely to be extensively usod for many years, and an understanding of these processes is ossential to encourage and standardize tho production of fish and other foods of high acceptability and nutritivo value.

It is a pity that the report of the Institute for 1960-61 was not publishod moro promptly, as for more recent information it is necessary to consult Indian journals some of which have only a limitod circulation. Clearly, however, the workers at Mysore are aware of the importance of increasing food supplies to meet the needs of the growing population and are making a real contribution to the problem from the tochnological side. Ono hopes that the limitation of human fertility is receiving the same attontion olsowhere.
D. S. Muller

\section{POTASSIUM-ARGON AGES FROM WESTERN OAHU, HAWAII}

\section{By IAN MCDOUGALL}

\section{Department of Geophysics, Australian National University, Canberra}

T HE large shield volcanoes which comprise the Hawaiian Islands have been the subject of intensive study for many years. Little is known concerning the absolute age of the lavas or the time involved in building these shield volcanoes. Previous workers have based their estimates of age on superposition and geomorphological arguments. A study of the age of the Hawailan Islands by using the potassium-argon method, mainly on whole-rock samples, is in progress. In this preliminary communication results are given of ages from Western Oahu.

The Waianae Volcano comprises the western half of Oahu, and the volcanic sequence has been divided into the Lower, Middle and Upper Waianae Series ${ }^{1,2}$. The volcano has been profoundly eroded into wide, flatfloored valleys up to $3,000 \mathrm{ft}$. doep, separated by steep, rugged ridges.

Specimens were collected from the Mauna Kuwalo hornblende-biotite-trachyte ${ }^{1,2}$, and basaltic rocks of the Middle and Upper Waianae Series. Biotite was separated from the trachyte and used for dating this rock. The age of each of the basaltic rocks was determined on whole. rock samples; about $10 \mathrm{~g}$ of sample was used for each argon extraction. The extractions were made in a high vacuum line by fusing the sample, adding a tracer of argon-38, followed by purification of the argon over hot copper oxide and calcium. The isotopic composition of the argon was determined on a Reynolds-type mass spectrometer by the static $\operatorname{mothod}^{3}$. Potassium was measured on a Perkin Elmer flame photometer using lithium as an internal standard; sodium was added as a buffer to both the sample solutions and the standards. Results are given in Table 1, and details of the samples are listed in tho appendix. Replicate potassium analyses agree to better than 1 per cent. Duplicate argon extractions agree to better than $2 \cdot 5$ per cent in those cases where the air argon correction is less than 60 per cent; where this correction is greater the precision decreases owing to marked error magnification. The absolute accuracy is probably \pm 3 per cent, increasing to \pm 6 per cent in those samples with a high air correction, excluding uncertainties in the decay constants. The marked dis. agreement between replicate argon extractions for GA560 is partly because of the high air correction, and partly because of sampling difficulties, as this basalt is amygdaloidal. The fact that the rocks show no evidence of alteration, and that thoy have never been deoply buriod, renders it unlikely that appreciable loss of argon has occurred.

Biotite from the Mauna Kuwale trachyte gives an age of $8 \cdot 4 \pm 0 \cdot 2$ million years, corresponding to the Lower to Middle Pliocene, based on the time scale of Kulp ${ }^{4}$. The basalts of the Middle and Upper Waianae Series yield Upper Pliocene ages ranging from $3.5 \pm 0.3$ to $2.75 \pm$ $0 \cdot 1 \mathrm{~m} . \mathrm{y}$.

Stearns and Vaksvik ${ }^{1}$ included the Mauna Kuwale trachyte in the Lower Waianae Series, regarded as the oldest exposed rocks of Oahu. The trachyte is overlain conformably to the south-west by basalts mapped as Lower and/or Middle Waianae Series ${ }^{2}$. Because silicic lavas are generally associated with the declining stages of activity in the Hawaiian volcanoes and the Lower Waianae Series is composed predominantly of tholeiitic basalts, it was suggested $^{1}$ that, alternatively, the trachyte may be associated with an older volcano buried by the later Waianae lavas. The potassium-argon age of the trachyte may lend support for this hypothesis, as the Middle and Upper Waianao Series volcanics are much younger; the results clearly show that there was a prolonged hiatus between the extrusion of the trachyte and the outpouring of the lavas of the Middle and Upper Waianae Series.

The Middle Waimnae Series lavas are only slightly older than those of the Upper Waianao Series. Hence. extrusion of the lavas of these two series apparently occurred rapidly, and the change in composition from dominantly tholeiitic to dominantly alkali-olivine basalts, on which the division betwoen the two serios is made, occurred over a relatively short period of time.

These results provide some hitherto non-existent control as to the absolute age of the volcanics of Western Oahu, and show that the estimates of age based on geomorphological arguments are qualitatively correct. Thus, Stearns and Vaksvik ${ }^{1}$ suggested that the deep valleys of Oahu probably were eroded during early Pleistocene time, by correlating the emerged coral reefs with shifts of sea-lovel induced by glaciation. They concluded that the building of Koolau Volcano (Eastern Oahu) ceased in the late 